\title{
Production of potato minitubers by repeated harvesting: plant productivity and initiation, growth and resorption of tubers
}

\author{
W.J.M. LOMMEN \& P.C. STRUIK \\ Department of Agronomy, Wageningen Agricultural University, Haarweg 333, NL 6709 RZ \\ Wageningen, Netherlands
}

Received 28 November 1991; accepted 16 April 1992

\begin{abstract}
Plant growth and tuber initiation, growth and resorption were studied in two potato cultivars, grown for minituber production under tuber inducing conditions. Plants were harvested up to three times within 11 weeks, using one or two non-destructive harvests at which minitubers $(\geqslant 0.3 \mathrm{~g})$ were removed and plants were replanted. The first non-destructive harvest stimulated the initiation of new tubers. A part of these tubers grew to a size of $\geqslant 0.3 \mathrm{~g}$ within three weeks. The other tubers remained $<0.3 \mathrm{~g}$ and many of them were resorbed during plant senescence. A second non-destructive harvest, three to four weeks after the first harvest, stimulated initiation of new tubers only in young plants of one cultivar, but always stimulated growth of tubers that otherwise would have been resorbed or would have remained $<0.3 \mathrm{~g}$. Again, a part of the tubers grew to a size of $\geqslant 0.3 \mathrm{~g}$ within three weeks. Thus, the number of minitubers increased after both non-destructive harvests. Tuber and overall growth rates, however, were reduced. A production scheme for practical minituber production is suggested, consisting of 3 harvests and yielding over 1800 minitubers per $\mathrm{m}^{2}$, all $\geqslant 0.3 \mathrm{~g}$ and weighing on average $1-2 \mathrm{~g}$.
\end{abstract}

Keywords: Solanum tuberosum L., minitubers, rapid multiplication, growth rate, tuberization, tuber pruning, non-destructive harvest

\section{Introduction}

Minitubers are small seed potato tubers, produced in the glasshouse on in vitro propagated plantlets, planted in a high density. They are considered to be the most suitable progagule to reduce the number of field multiplications in a seed programme (Lommen \& Struik, 1992). The production of minitubers consists of two phases: (1) the multiplication of plantlets in vitro and (2) the production of minitubers on these plantlets in the glasshouse. This paper deals with the second phase.

Previous research showed that the number of minitubers could be increased by $100 \%-250 \%$ if plants were harvested twice instead of once, using a non-destructive harvesting procedure in the first harvest (Lommen \& Struik, 1992) at which 
tubers $\geqslant 0.3 \mathrm{~g}$ were removed and plants were replanted. Three weeks later, the plants were harvested a second time. A weight of $0.3 \mathrm{~g}$ was used as a lower limit for being counted as a minituber.

The non-destructive harvest stimulated the initiation of new stolons and tubers, but the majority of the newly initiated tubers was smaller than $0.3 \mathrm{~g}$ at the second harvest. Number of minitubers in the second harvest, and overall and tuber growth rates between two harvests depended on the age of the plants at the first harvest. Highest number of minitubers in the second harvest was produced when the first harvest took place in the period of maximum plant growth. The timing of the first harvest was very critical, but it was impossible to asses it on the basis of plant habitus.

From a practical point of view, two questions remained: (1) how are minituber numbers at the second harvest affected by extending the growing period between two harvests and (2) how can high numbers of minitubers be produced reliably? For answering these questions one needs a better understanding of tuber formation after a non-destructive harvest.

The number of minitubers in a second harvest will depend on (a) the total number of tubers remaining on the plant after the first harvest and initiated thereafter and (b) the proportion of these tubers that is able to grow to the desired weight before the second harvest. The length of the growing period between two harvests might be crucial for the tuber numbers in different grades at the second harvest. Therefore, the effects of extending the growing period between two harvests, on tuber numbers in different grades and growth rates of different plant parts are described in this paper. In addition, the effects of a second non-destructive harvest were investigated. The cultivar choice, the non-destructive harvesting procedure and the experimental conditions were similar to the ones described previously (Lommen \& Struik, 1992). A production scheme for practical production of minitubers will be suggested, aiming at high numbers of minitubers per $\mathrm{m}^{2}$ and suitable for different cultivars.

\section{Materials and methods}

\section{In vitro multiplication}

In vitro plantlets of Solanum tuberosum L. cv. Ostara (early) and cv. Bintje (midearly) were produced by subculturing single-node stem cuttings approximately every 4 weeks. Temperature in the growth room was $23^{\circ} \mathrm{C}$, photoperiod 16 hours and light was supplied by fluorescent tubes (Philips 33) at an intensity of $8 \mathrm{~W} \mathrm{~m}^{-2}$. The multiplication medium, $\mathrm{pH} 5.7$, contained mineral salts and vitamins according to Murashige and Skoog (1962), $2.0 \mathrm{mg} \mathrm{l}^{-1}$ glycine, $8.0 \mathrm{~g} \mathrm{l}^{-1}$ agar and $25.0 \mathrm{~g} \mathrm{l}^{-1}$ sucrose. To the normalization medium before transplanting an additional $0.01 \mathrm{~g} \mathrm{l}^{-1}$ alar-85\% (daminozide) was added.

In vitro plantlets were produced using the same procedure as before (Lommen \& Struik, 1992), but the length of the growing period on the normalization medium from the last subculturing until transplanting was 8 to 11 days, and therefore shorter than in earlier research. 
In vitro plantlets were transplanted in a controlled glasshouse into $13 \times 13 \times 13 \mathrm{~cm}$ pots with a mixture of perlite and potting soil $(50 / 50 \% \mathrm{v} / \mathrm{v})$. Available $\mathrm{N}$ from the soil medium was approximately $230 \mathrm{mg}$ per pot. A plant density of 350 plants $\mathrm{m}^{-2}$ was obtained by planting 6 plants per pot in a row in the middle of the pot, spaced approximately $2.2 \mathrm{~cm}$ from each other and joining all pots. This plant density was maintained throughout the experiment. One row of guard pots surrounded the experiment.

The experiment was carried out in a glasshouse at Wageningen, The Netherlands, during summer (June 14 - August 30, 1988; in contrast with previous research, which was carried out in winter; Lommen \& Struik, 1992). Photoperiod was reduced to 12 hours and natural light was supplemented to at least $80 \mathrm{~W} \mathrm{~m}^{-2}$ (total radiation) by high-pressure sodium lamps (Philips SON-T). Day temperature was set at $18^{\circ} \mathrm{C}$, night temperature at $12^{\circ} \mathrm{C}$. After 63 days, every pot received $100 \mathrm{ml}$ of a low concentrated nutrient solution $\left(\mathrm{Ca}\left(\mathrm{NO}_{3}\right)_{2} .4 \mathrm{H}_{2} \mathrm{O} 0.890 \mathrm{~g} \mathrm{l}^{-1}, \mathrm{KNO}_{3} 0.446 \mathrm{~g} \mathrm{l}^{-1}, \mathrm{KH}_{2} \mathrm{PO}_{4} 0.135\right.$ $\mathrm{g} \mathrm{l}^{-1}, \mathrm{~K}_{2} \mathrm{SO}_{4} 0.140 \mathrm{~g} \mathrm{l}^{-1}, \mathrm{MgSO}_{4} .7 \mathrm{H}_{2} \mathrm{O} 0.472 \mathrm{~g} \mathrm{l}^{-1}, \mathrm{H}_{2} \mathrm{SO}_{4} 0.034 \mathrm{~g} \mathrm{l}^{-1}$, FeEDTA $0.035 \mathrm{~g}$ $\mathrm{I}^{-1}, \mathrm{MnSO}_{4} \cdot 1 \mathrm{H}_{2} \mathrm{O} 2.0 \mathrm{mg} \mathrm{l}^{-1}, \mathrm{H}_{3} \mathrm{BO}_{3} 3.0 \mathrm{mg} \mathrm{l}^{-1}, \mathrm{ZnSO}_{4} \cdot 7 \mathrm{H}_{2} \mathrm{O} 0.5 \mathrm{mg} \mathrm{l}^{-1}$, $\mathrm{Na}_{2} \mathrm{MoO}_{4} .2 \mathrm{H}_{2} \mathrm{O} 0.1 \mathrm{mg} \mathrm{l}^{-1}$ and $\mathrm{CuSO}_{4} .5 \mathrm{H}_{2} \mathrm{O} 0.1 \mathrm{mg} \mathrm{l}^{-1}, \mathrm{pH} 6.0$ ). Thus, nutrients were supplied 5 days later in a lower dose than in previously described research (Lommen \& Struik, 1992).

\section{Treatments and experimental design}

Plants grew undisturbed, or were harvested non-destructively and replanted one or two times. At a non-destructive harvest, all tubers $\geqslant 0.3 \mathrm{~g}$ were removed. The removal of tubers was carried out, using a procedure suitable for practical use (Lommen \& Struik, 1992). Root damage could not be avoided, but care was taken not to damage stems and stolons. Plants were replanted in the same soil, deeper than initially. At the final harvest of each treatment, plants were analyzed completely (destructive harvest). The number and timing of the harvests varied. All treatments are schematically presented in Fig. 1. Treatment codes represent the weeks after transplanting at which the (non-destructive and final/destructive) harvests in a treatment took place.

The experimental unit was a pot containing 6 plants. Results, however, will generally be expressed on a per plant basis. Pots were arranged in a complete randomized design with 6 replications, 2 cultivars and 16 treatments.

\section{Plant analysis}

At a non-destructive harvest, only tubers $\geqslant 0.3 \mathrm{~g}$ were harvested. At the final harvest, tubers were graded into 2 fresh weight classes: $\geqslant 0.3 \mathrm{~g}$ and $<0.3 \mathrm{~g}$. Plants were divided into leaves (petioles, rachides + leaflets), stems, stolons, roots and tubers. Stem length and node number of the main stem were recorded. Branching hardly occurred. Node number included the nodes of all visible leaves in the top. Growth 


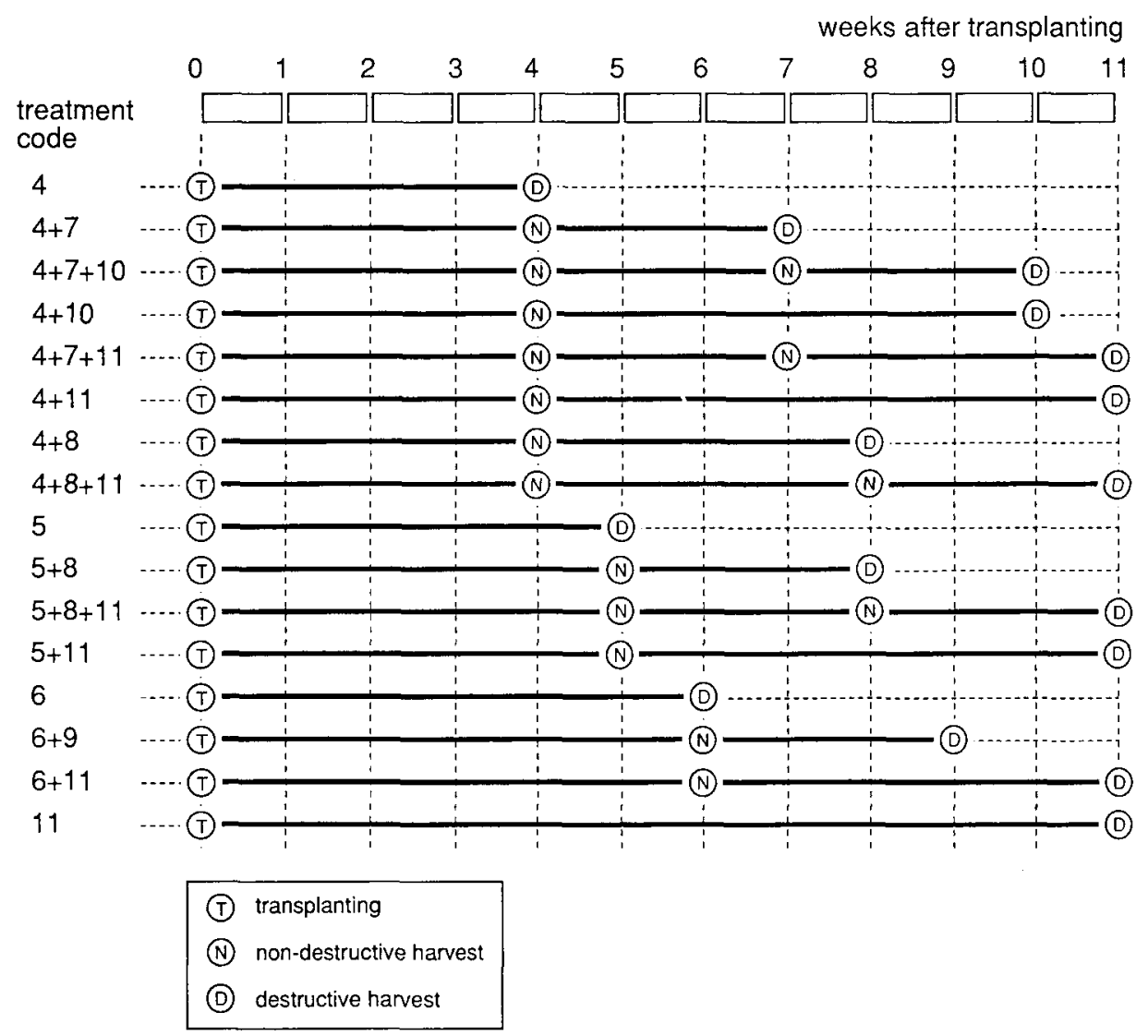

Fig. 1. Treatment codes and schematic explanation of treatments.

rates (GRs) were calculated from the dry weight data at the final (destructive) harvests, for different plant fractions; leaves, stems and stolons at the final harvests were combined into a non-tuber fraction and tubers from all harvests were combined into a tuber fraction. Growth rates presented are mean growth rates. They were calculated over variable periods, comprising different growth phases, but are always expressed in $\mathrm{g} \mathrm{m}^{-2}$ day $^{-1}$. More details on methods were described by Lommen \& Struik (1992).

\section{Definitions}

Plant age: time passed since the transplanting of the in vitro plantlets to the glasshouse.

Minituber number: number of tubers $\geqslant 0.3 \mathrm{~g}$.

Total tuber number: number of tubers $>0.0 \mathrm{~g}$.

Combined tuber number: the sum of the number of tubers from non-destructive 
harvest(s) (always $\geqslant 0.3 \mathrm{~g}$ ) and final harvest (respectively $\geqslant 0.3 \mathrm{~g}$ and $>0.0 \mathrm{~g}$, for combined number of minitubers and combined total tuber number).

Actual tuber number: number of tubers present at the plant.

\section{Results}

Stolon and tuber characteristics after a first non-destructive harvest

Comparisons of treatments 4,5 and 6 (showing the situation at the first harvests), with treatments $4+7,5+8$ and $6+9$ (in which the growing period between the first and final harvest was 3 weeks), showed that the number of stolons only increased after a first non-destructive harvest of 5 and 6 weeks old plants of cv. Bintje (Table 1). Stolons were short (on average $1.6 \mathrm{~cm}$ ), both at the first non-destructive harvest and 3 weeks later (Table 1).

In the 3-weeks growing period between the first and final harvest, many new tubers were initiated (Figs. 2A and 2B). Most tubers were initiated in the 3-weeks growing period after a non-destructive harvest of 6 weeks old plants in cv. Ostara and 5 weeks old plants in cv. Bintje. However, the influence of plant age on the initiated number of tubers was smaller in cv. Ostara (Fig. 2A) than in cv. Bintje (Fig. 2B). Three weeks after a first non-destructive harvest, a much larger proportion of
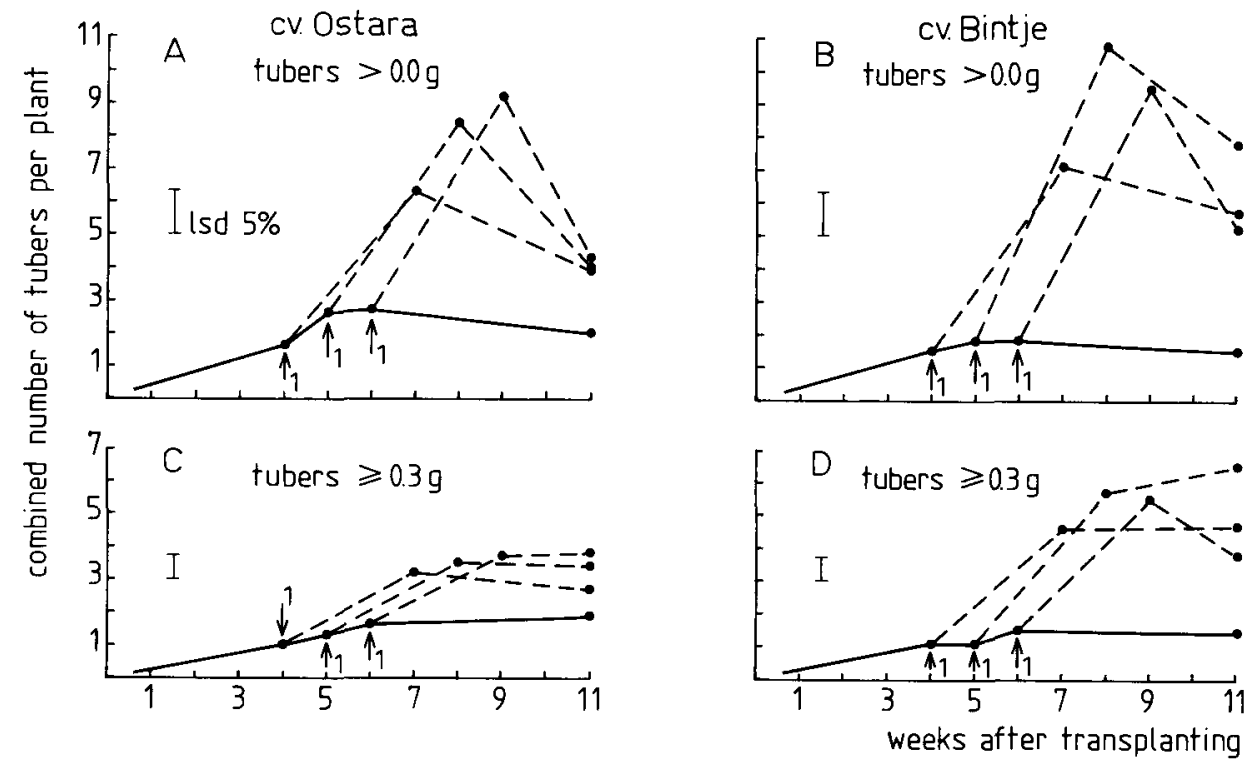

Fig. 2. Development over time of the combined number of tubers from all harvests of plants growing undisturbed and after a first non-destructive harvest that took place 4,5 or 6 weeks after transplanting. Total number of tubers $(>0 \mathrm{~g})$ of cvs. Ostara (A) and Bintje (B); number of minitubers ( $\geqslant 0.3 \mathrm{~g})$ of cvs. Ostara (C) and Bintje (D). Undisturbed growth $\longrightarrow$. After first non-destructive harvest - - . Arrows indicate first non-destructive harvest. 
W.J.M. LOMMEN AND P.C. STRUIK

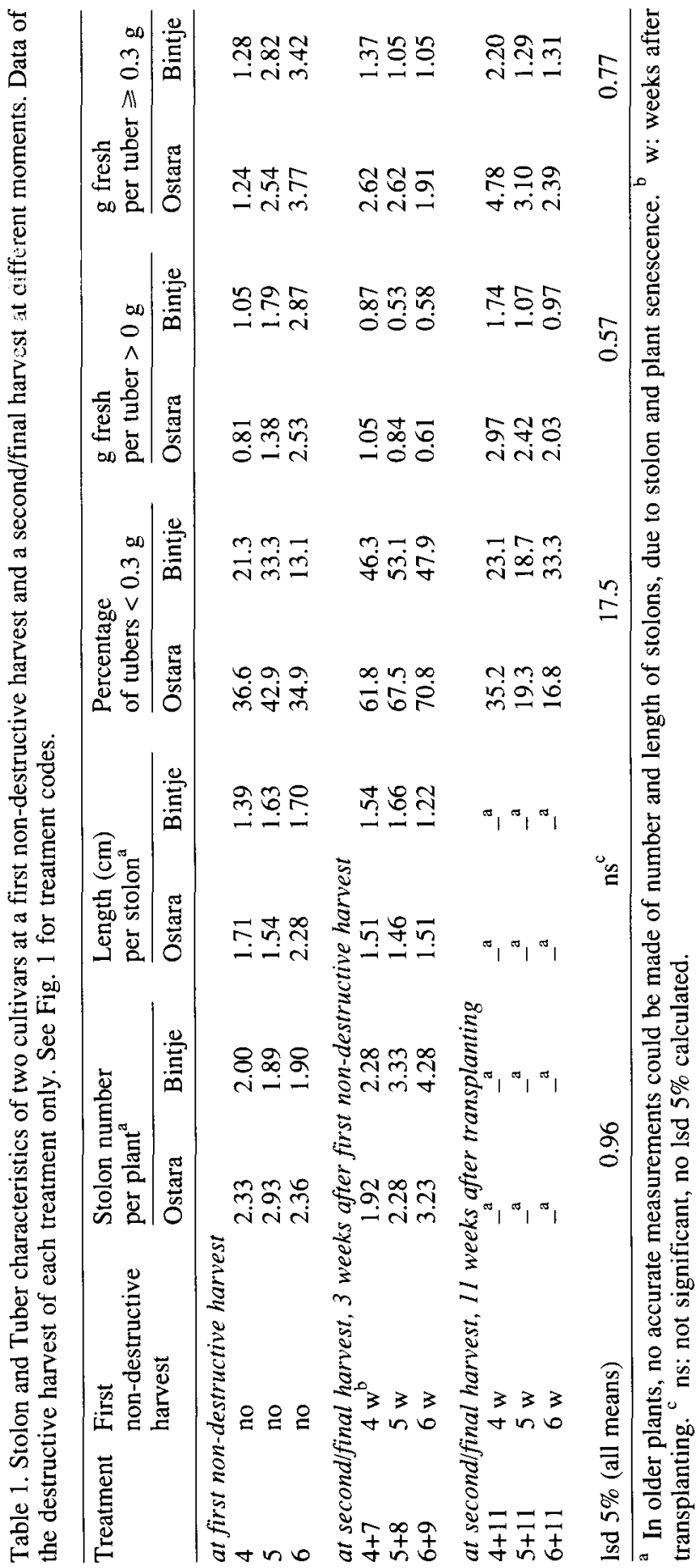


the tubers was $<0.3 \mathrm{~g}$ than before (Table 1). This proportion was much larger in $\mathrm{cv}$. Ostara than in cv. Bintje.

If the final harvest was postponed from 3 weeks after the first harvest (treatments $4+7,5+8$ and $6+9$ ) till 11 weeks after transplanting (treatments $4+11,5+11$ and $6+11$ ), the total number of tubers decreased: many of the newly initiated small tubers were resorbed (Figs. $2 \mathrm{~A}$ and $2 \mathrm{~B}$ ). The later the first harvest, the more tubers were resorbed in the period from 3 weeks after the first harvest till 11 weeks after transplanting.

Although extending the growing period from 3 weeks after the non-destructive harvest till 11 weeks after transplanting decreased total tuber numbers, it hardly affected the number of tubers $\geqslant 0.3 \mathrm{~g}$ (Figs. 2C and 2D). No significant increase was observed. When cv. Bintje was harvested late for the first time, extending the growing period even significantly reduced the number of tubers $\geqslant 0.3 \mathrm{~g}$ (Fig. 2D). The average weight per tuber, however, increased by extending the growing period (Table 1 ).

\section{Growth rates after a first non-destructive harvest}

Table 2 shows that from 4 to 6 weeks after transplanting (the moments at which the first harvests took place) no new leaf appearance occurred in undisturbed plants, but stems were still elongating. Leaf dry weight reached its maximum 5 weeks after transplanting, but dry weights of most other plant parts increased until at least 6 weeks after transplanting. Total dry weight of the non-tuber fraction (excluding roots) was highest 6 and 5 weeks after transplanting for cvs. Ostara and Bintje respectively (not shown). On average, tubers made up $30 \%$ of the dry matter when young (4 weeks) plants were harvested for the first time and $62 \%$ when older ( 6 weeks) plants were harvested for the first time.

During the 3 weeks after a non-destructive harvest of 4 weeks old plants, the dry weight of the non-tuber fraction hardly changed: growth rates (GRs) were around zero (Table 3). However, during the 3 weeks after a non-destructive harvest of older plants, GRs of the non-tuber fraction were negative. In contrast, tuber GRs were positive and not affected by the age of the plants at the first harvest (Table 3). Overall GRs during the first 3 weeks after a non-destructive harvest were positive, but slightly lower (though not significantly so) when plants were older at the first harvest.

When the second harvest was postponed till 11 weeks after transplanting, nontuber GRs in the period from 3 weeks after the non-destructive harvest till 11 weeks after transplanting, were clearly negative (Table 3 ). The later the first non-destructive harvest, the more negative these GRs. Tuber and overall GRs during this time interval were lower, the later the first harvest. Due to severe plant senescence, all three GRs were negative when the growing period after a harvest of 6 weeks old plants was extended from 9 to 11 weeks after transplanting (Table 3). This could not be explained merely by the period over which GRs were calculated: when the nondestructive harvest took place 4 weeks after transplanting, overall and tuber GRs were even positive in the last week (not shown). 
W.J.M. LOMMEN AND P.C. STRUIK

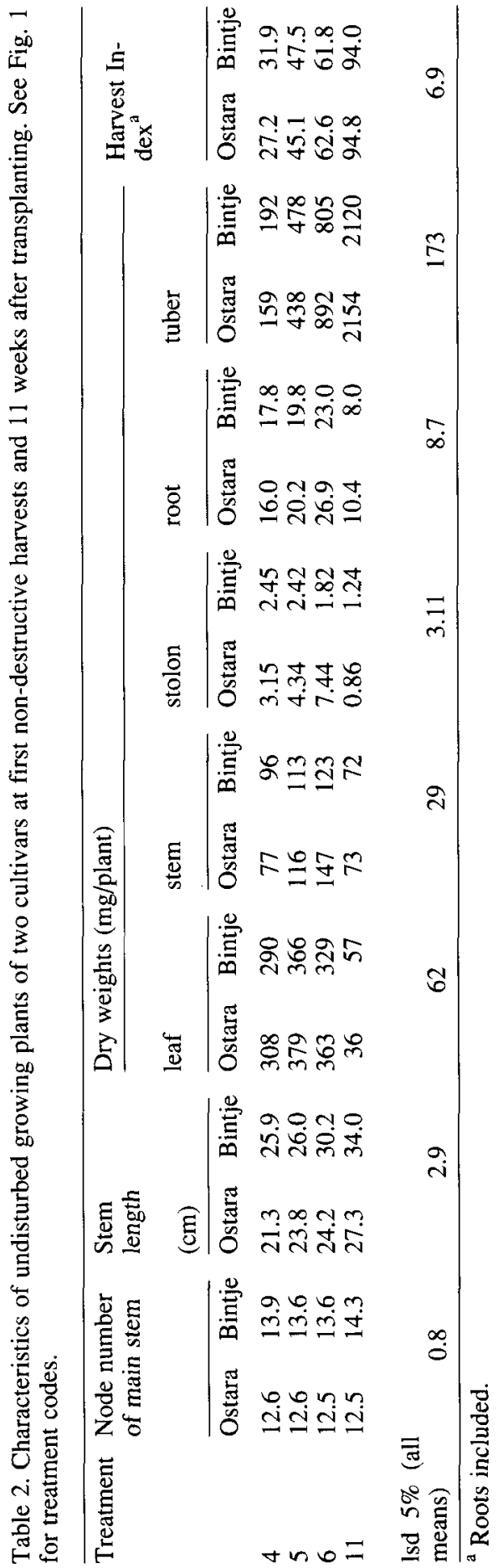


Table 3. Growth rates (GRs) in $\mathrm{g} \mathrm{m}^{-2} \mathrm{~d}^{-1}$ of different plant fractions of two cultivars from a first non-destructive harvest at different moments till 3 weeks after the non-destructive harvest and from 3 weeks after the non-destructive harvest till 11 weeks after transplanting.

\begin{tabular}{|c|c|c|c|c|c|c|c|}
\hline \multirow{2}{*}{$\begin{array}{l}\text { Timing of first } \\
\text { non-destructive } \\
\text { harvest }\end{array}$} & \multirow{2}{*}{$\begin{array}{l}\text { Period during which } \\
\text { GRs were calculated }\end{array}$} & \multicolumn{2}{|c|}{ Non-tuber GR } & \multicolumn{2}{|c|}{ Tuber GR } & \multicolumn{2}{|c|}{ Overall GR } \\
\hline & & Ostara & Bintje & Ostara & Bintje & Ostara & Bintje \\
\hline \multicolumn{8}{|c|}{ from non-destructive harvest till 3 weeks after non-destructive harvest } \\
\hline $4 w^{a}$ & $4 w-7 w$ & +0.2 & -0.5 & +14.0 & +13.9 & +14.2 & +13.4 \\
\hline $5 w$ & $5 w-8 w$ & -1.9 & -2.3 & +14.8 & +1 & .8 & +10.9 \\
\hline $6 \mathrm{w}$ & $6 w-9 w$ & -3.2 & -2.1 & +13.0 & +13.0 & +9.0 & +10.9 \\
\hline lsd $5 \%$ & & \multicolumn{2}{|c|}{1.5} & \multicolumn{2}{|c|}{$\mathrm{ns}^{\mathrm{b}}$} & \multicolumn{2}{|c|}{ ns } \\
\hline \multicolumn{8}{|c|}{ from 3 weeks after non-destructive harvest till 11 weeks after transplanting } \\
\hline $4 w$ & $7 w-11 w$ & -3.4 & -3.3 & +11.8 & +7.5 & +8.4 & +4.2 \\
\hline $5 w$ & $8 w-11 w$ & -4.6 & -4.1 & +5.1 & +8.4 & +0.5 & +4.3 \\
\hline $6 \mathrm{w}$ & $9 w-11 w$ & -5.9 & -5.5 & -0.3 & -5.3 & -6.2 & -10.8 \\
\hline \multicolumn{2}{|l|}{ Isd $5 \%$} & \multicolumn{2}{|r|}{1.3} & \multicolumn{2}{|c|}{9.9} & \multicolumn{2}{|c|}{10.4} \\
\hline
\end{tabular}

${ }^{a}$ w: weeks after transplanting. ${ }^{b}$ ns: not significant, no lsd $5 \%$ calculated.

Compared to undisturbed growing plants, a first non-destructive harvest did not affect GRs of the non-tuber fraction over the time interval from the non-destructive harvest moment till 11 weeks after transplanting (Table 4). Tuber and overall GRs, however, were reduced strongly by a non-destructive harvest. The later the first non-destructive harvest, the more severe the reduction.

Table 4. Growth rates (GRs) in $\mathrm{g} \mathrm{m}^{-2} \mathrm{~d}^{-1}$ of different plant fractions of two cultivars after a first non-destructive harvest at different moments and during undisturbed growth from the non-destructive harvest moments until 11 weeks after transplanting.

\begin{tabular}{|c|c|c|c|c|c|c|c|}
\hline \multirow{2}{*}{$\begin{array}{l}\text { Timing of first } \\
\text { non-destructive } \\
\text { harvest }\end{array}$} & \multirow{2}{*}{$\begin{array}{l}\text { Period during } \\
\text { which GRs were } \\
\text { calculated }\end{array}$} & \multicolumn{2}{|c|}{ Non-tuber GR } & \multicolumn{2}{|c|}{ Tuber GR } & \multicolumn{2}{|c|}{ Overall GR } \\
\hline & & Ostara & Bintje & Ostara & Bintje & Ostara & Bintje \\
\hline \multicolumn{8}{|c|}{ after a first non-destructive harvest } \\
\hline $4 w^{a}$ & $4 w-11 w$ & -1.9 & -2.1 & +12.8 & +10.2 & +10.9 & +8.1 \\
\hline $5 \mathrm{w}$ & $5 w-11 w$ & -3.3 & -3.2 & +9.9 & +10.8 & +6.7 & +7.6 \\
\hline \multirow{2}{*}{$6 \mathrm{w}$} & $6 w-11 w$ & -4.3 & -3.5 & +7.7 & +5.7 & +3.0 & +2.3 \\
\hline & \multicolumn{7}{|c|}{ without first non-destructive harvest } \\
\hline no & $4 w-11 w$ & -2.0 & -1.8 & +14.2 & +13.8 & +12.3 & +11.9 \\
\hline no & $5 w-11 w$ & -3.2 & -2.9 & +14.3 & +13.7 & +11.1 & +10.8 \\
\hline no & $6 w-11 w$ & $\begin{array}{l}-4.2 \\
\text { mean: }\end{array}$ & $\begin{array}{l}-3.2 \\
-2.9\end{array}$ & $\begin{array}{l}+12.6 \\
\text { mean: }\end{array}$ & $\begin{array}{l}+13.2 \\
+13.6\end{array}$ & $\begin{array}{l}+8.0 \\
\text { mean: }\end{array}$ & $\begin{array}{l}+9.9 \\
+10.7\end{array}$ \\
\hline \multicolumn{2}{|c|}{ lsd $5 \%$ (all means) } & \multicolumn{2}{|r|}{0.7} & \multicolumn{2}{|r|}{3.0} & \multicolumn{2}{|c|}{3.2} \\
\hline \multicolumn{2}{|c|}{$\begin{array}{l}\text { significance } \\
\text { of effect of non-destructive harvest }{ }^{b}\end{array}$} & & ns & \multicolumn{2}{|c|}{$* * *^{\mathrm{c}}$} & \multicolumn{2}{|c|}{$* * *$} \\
\hline
\end{tabular}



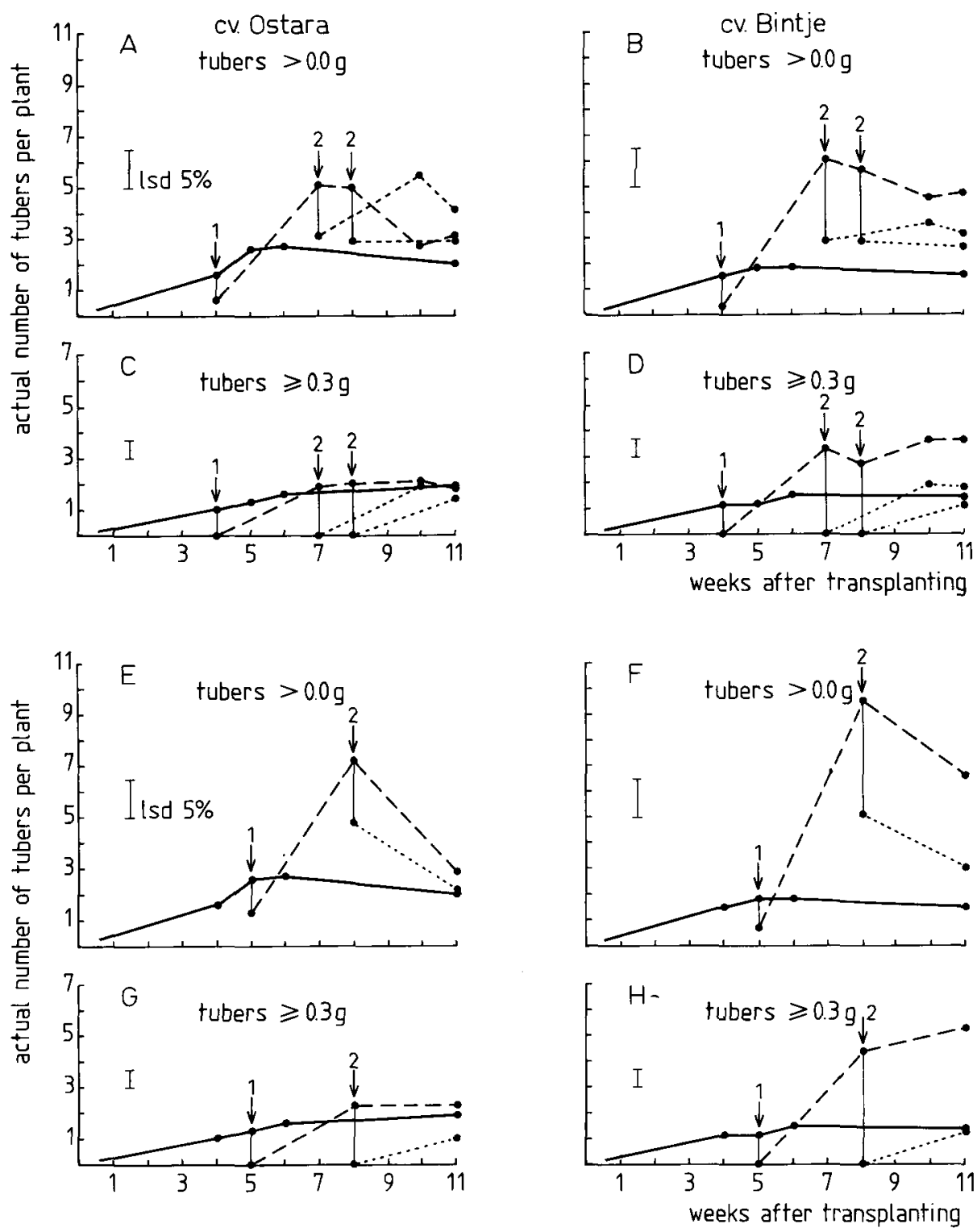

Fig. 3. Development over time of the actual number of tubers, present on plants growing undisturbed and after one and two non-destructive harvests. Total number of tubers ( $>0.0 \mathrm{~g})$ of cvs. Ostara (A) and Bintje (B), and number of minitubers ( $\geqslant 0.3 \mathrm{~g}$ ) of cvs. Ostara (C) and Bintje (D) when the first non-destructive harvest took place 4 weeks after transplanting; total number of tubers of cvs. Ostara (E) and Bintje (F), and number of minitubers of cvs. Ostara $(G)$ and Bintje $(H)$ when the first non-destructive harvest took place 5 weeks after transplanting. Undisturbed growth After first non-destructive harvest - - - . After second non-destructive harvest - - - . Arrows indicate first or second non-destructive harvest. 
Tuber characteristics after a second non-destructive harvest

In the 3-weeks growing period between a second and third harvest, no initiation of new tubers was observed (Figs. 3A, 3B, 3E, 3F), except in cv. Ostara when the second harvest took place 7 weeks after transplanting (Fig. 3A, comparison of treatments $4+7$ and $4+7+10$ ). After a second harvest of 8 -week-old plants, total tuber number remained constant when the first harvest had taken place 4 weeks after transplanting (Figs. 3A and 3B, comparison of treatments $4+8$ and $4+8+11$ ), but decreased when the first harvest had taken place 5 weeks after transplanting (Figs. $3 \mathrm{E}$ and $3 \mathrm{~F}$, comparison of treatments $5+8$ and $5+8+11$ ).

In all cases tubers $\geqslant 0.3 \mathrm{~g}$ were still formed after all tubers $\geqslant 0.3 \mathrm{~g}$ were removed in a second non-destructive harvest (Figs. 3C, 3D, 3G and 3H). Approximately half of the tubers had not reached a size of $\geqslant 0.3 \mathrm{~g}$ within $3-4$ weeks after a second harvest (Table 5). The average fresh weight of all tubers was higher than $0.3 \mathrm{~g}$, while the average fresh weight of the tubers $0.3 \mathrm{~g}$ in general was higher than $1 \mathrm{~g}$ (Table 5).

\section{Growth rates after a second non-destructive harvest}

After a second non-destructive harvest, non-tuber GRs were always negative (Table 6). The decreases in non-tuber dry weight were similar to the decreases in plants left undisturbed after a first non-destructive harvest. Tuber GRs generally were positive, but were less than half of tuber GRs of plants left undisturbed after the first nondestructive harvest (Table 6). Compared to plants left undisturbed after the first harvest, a second harvest reduced overall GRs severely. Overall GRs were slightly positive or negative after the second harvest, except during the 3 weeks after the earliest harvest (Table 6).

Table 5. Tuber characteristics of two cultivars, at a second non-destructive harvest and a third/final harvest at different moments. Data of the destructive harvest of each treatment only. See Fig. 1 for treatment codes.

\begin{tabular}{|c|c|c|c|c|c|c|c|c|}
\hline \multirow[t]{2}{*}{ Treatment } & \multirow{2}{*}{$\begin{array}{l}\text { First } \\
\text { non-destructive } \\
\text { harvest }\end{array}$} & \multirow{2}{*}{$\begin{array}{l}\text { Second } \\
\text { non-destructive } \\
\text { harvest }\end{array}$} & \multicolumn{2}{|c|}{$\begin{array}{l}\text { Percentage of } \\
\text { tubers }<0.3 \mathrm{~g}\end{array}$} & \multicolumn{2}{|c|}{$\begin{array}{l}\mathrm{g} \text { fresh } \\
\text { per tuber }>0 \mathrm{~g}\end{array}$} & \multicolumn{2}{|c|}{$\begin{array}{l}\mathrm{g} \text { fresh } \\
\text { per tuber } \geqslant 0.3 \mathrm{~g}\end{array}$} \\
\hline & & & Ostara & Bintje & Ostara & Bintje & Ostara & Bintje \\
\hline \multicolumn{9}{|c|}{ at second non-destructive harvest } \\
\hline $4+7^{\mathrm{a}}$ & yes & no & 61.8 & 46.4 & 1.05 & 0.87 & 2.62 & 1.37 \\
\hline $4+8$ & yes & no & 53.1 & 47.7 & 1.76 & 1.22 & 3.40 & 2.14 \\
\hline $5+8^{a}$ & yes & no & 67.5 & 53.1 & 0.84 & 0.53 & 2.62 & 1.05 \\
\hline \multicolumn{9}{|c|}{ at thirdlfinal harvest } \\
\hline $4+7+10$ & yes & yes & 61.6 & 43.6 & 0.66 & 0.68 & 1.63 & 1.13 \\
\hline $4+7+11$ & yes & yes & 47.1 & 43.7 & 1.13 & 0.82 & 2.16 & 1.31 \\
\hline $4+8+11$ & yes & yes & 45.9 & 55.8 & 0.62 & 0.45 & 1.14 & 0.83 \\
\hline $5+8+11$ & yes & yes & 55.9 & 55.1 & 0.50 & 0.57 & 1.05 & 1.13 \\
\hline \multicolumn{3}{|c|}{ lsd 5\% (all means) } & \multicolumn{2}{|c|}{17.4} & \multicolumn{2}{|c|}{0.58} & \multicolumn{2}{|c|}{0.72} \\
\hline
\end{tabular}

${ }^{\mathrm{a}}$ Same values as shown in Table 1. 
Table 6. Growth rates (GRs) in $\mathrm{g} \mathrm{m}^{-2} \mathrm{~d}^{-1}$ of different plant fractions of two cultivars after a second non-destructive harvest and during undisturbed growth after a first non-destructive harvest.

\begin{tabular}{|c|c|c|c|c|c|c|c|c|}
\hline \multirow{2}{*}{$\begin{array}{l}\text { Timing of } \\
\text { first non- } \\
\text { destructive } \\
\text { harvest }\end{array}$} & \multirow{2}{*}{$\begin{array}{l}\text { Timing of } \\
\text { second non- } \\
\text { destructive } \\
\text { harvest }\end{array}$} & \multirow{2}{*}{$\begin{array}{l}\text { Period during } \\
\text { which GRs were } \\
\text { calculated }\end{array}$} & \multicolumn{2}{|c|}{ Non-tuber GR } & \multicolumn{2}{|c|}{ Tuber GR } & \multicolumn{2}{|c|}{ Overall GR } \\
\hline & & & Ostara & Bintje & Ostara & Bintje & Ostara & Bintje \\
\hline \multicolumn{9}{|c|}{ after a second non-destructive harvest } \\
\hline $4 w^{a}$ & $7 \mathrm{w}$ & $7 w-10 w$ & -3.2 & -3.3 & +8.9 & +5.4 & +5.6 & +2.1 \\
\hline $4 \mathrm{w}$ & $7 \mathrm{w}$ & $7 w-11 w$ & -2.8 & -3.4 & +7.8 & +2.1 & +5.0 & -1.4 \\
\hline $4 w$ & $8 \mathrm{w}$ & $8 w-11 w$ & -3.8 & -3.5 & +4.1 & +0.6 & +1.1 & -2.9 \\
\hline $5 \mathrm{w}$ & $8 w$ & $8 w-11 w$ & $\begin{array}{l}-5.4 \\
\text { mean: }\end{array}$ & $\begin{array}{l}-4.5 \\
-3.8\end{array}$ & $\begin{array}{l}-0.7 \\
\text { mean: }\end{array}$ & $\begin{array}{l}+5.0 \\
+4.2\end{array}$ & $\begin{array}{l}-6.1 \\
\text { mean: }\end{array}$ & $\begin{array}{l}+0.4 \\
+0.5\end{array}$ \\
\hline \multicolumn{9}{|c|}{ without second non-destructive harvest } \\
\hline $4 w$ & no & $7 w-10 w$ & -4.3 & -3.7 & +12.8 & +8.4 & +8.5 & +4.7 \\
\hline $4 w$ & no & $7 w-11 w^{b}$ & -3.4 & -3.3 & +11.8 & +7.5 & +8.4 & +4.2 \\
\hline $4 \mathrm{w}$ & no & $8 w-11 w$ & -3.2 & -3.1 & +10.5 & +7.2 & +7.4 & +4.0 \\
\hline $5 w$ & no & $8 w-11 w^{b}$ & $\begin{array}{l}-4.6 \\
\text { mean }\end{array}$ & $\begin{array}{r}-4.1 \\
-37\end{array}$ & +5.1 & $\begin{array}{l}+8.4 \\
+90\end{array}$ & +0.5 & $\begin{array}{r}+4.3 \\
+53\end{array}$ \\
\hline \multicolumn{3}{|c|}{ 1sd $5 \%$ (all means) } & & 1.2 & & 5.9 & \multicolumn{2}{|c|}{6.2} \\
\hline \multicolumn{3}{|c|}{$\begin{array}{l}\text { significance }^{\mathrm{c}} \\
\text { of effect of second non-de }\end{array}$} & $\mathrm{ns}$ & & $* * *$ & & \multicolumn{2}{|l|}{$* * *$} \\
\hline
\end{tabular}

\section{Combined tuber numbers}

For practical purposes, tubers from all harvests are of interest. Fig. 4 shows the combined tuber numbers. In cv. Ostara, highest tuber numbers were observed when plants were harvested three times, with treatment $4+7+10$ performing best (Figs. $4 \mathrm{~A}$ and $4 \mathrm{C}$ ). In cv. Bintje, however, the combined number of tubers was increased less by a second non-destructive harvest (Figs. 4B, 4D and 4F), especially when the timing of the first harvest was right ( 5 weeks after transplanting, Fig. $4 \mathrm{H}$ ). In this cultivar, highest number of tubers $>0.0 \mathrm{~g}$ was produced in treatment $5+8$ (Fig. 4F), highest number of minitubers $(\geqslant 0.3 \mathrm{~g})$ in plants left undisturbed after this first non-destructive harvest (treatment $5+11$, Fig. $4 \mathrm{H}$, while treatment $5+8$ did not differ significantly from treatment $5+11$ ). Averaged over both cultivars, however, treatment $4+7+10$ produced most minitubers. Prolonging the interval between the second and the third harvest (treatment $4+7+11$ ) did not increase the number of minitubers, averaged over two cultivars. Plants were senescing seriously at that time. When instead of 4 weeks after transplanting (treatment $4+7+10$ ) the first harvest was carried out 5 weeks after transplanting (treatment $5+8+11$ ), combined tuber numbers were lower, but not significantly. 

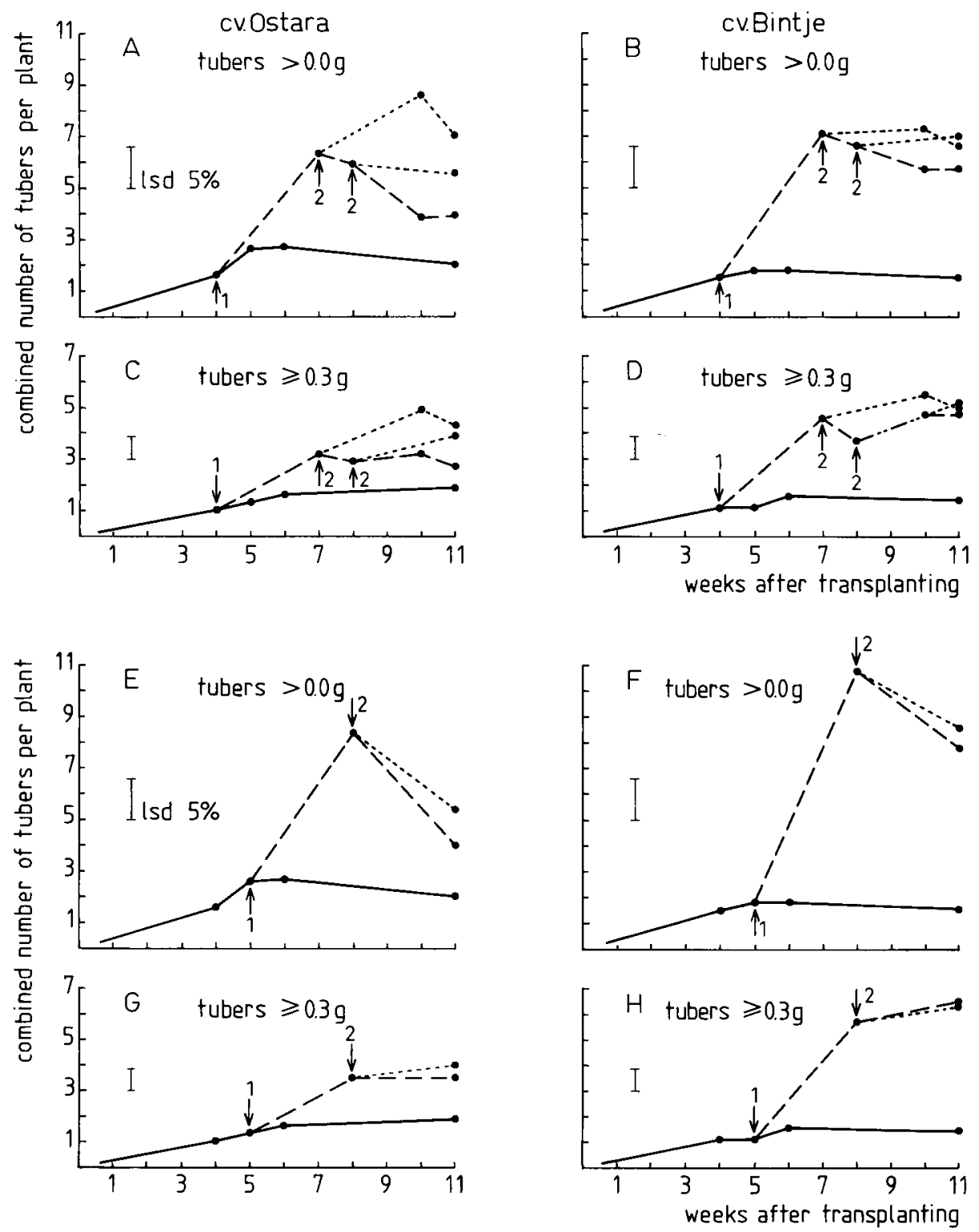

Fig. 4. Development over time of the combined number of tubers from all harvests of plants, growing undisturbed and after one and two non-destructive harvests. A to $\mathrm{H}$ and legend as in Fig. 3. 


\section{Discussion}

\section{Tuber initiation and resorption after a first non-destructive harvest}

The extensive initiation of new tubers that occurred within 3 weeks after removal of tubers in a first non-destructive harvest (Figs. 2A and 2B), confirms previous results (Lommen \& Struik, 1992) and results obtained by Oparka (1987) after removal of stolon apices and by Nösberger \& Humphries (1965) after removal of tubers plus stolons. This initiation of new tubers was attributed to the breaking of the dominance of the removed tuber and the deeper replanting of the plantlets after a non-destructive harvest, exposing more nodes to below ground conditions (Lommen \& Struik, 1992).

In the experiment described in this paper, the number of tubers initiated within 3 weeks after a first non-destructive harvest proved to be much higher than the number of tubers that finally set (Figs. 2A and 2B). Many tubers were resorbed. Similar results are reported with plants under field conditions, where considerable resorption of tubers is often observed after treatments causing the initiation of many tubers, like a high moisture level (Krug and Wiese, 1972), temperatures favouring early stem and haulm development (Cho \& Iritani, 1983) or the removal of stolon apices (Oparka 1987), if these treatments are followed by normal plant senescence. Ewing \& Struik (1992) suggested that after treatments causing extensive tuber initiation, the number of surviving tubers would not be increased, unless productivity also was increased by these treatments. In our experiment, however, no significant effect of a non-destructive harvest was observed on non-tuber GRs, and overall and tuber GRs even were reduced (Table 4). Still, 11 weeks after transplanting, tuber numbers $(>0.0 \mathrm{~g})$ in plants after a first non-destructive harvest, always were higher than in treatments in which plants grew undisturbed (Figs. 3A, 3B, 3E and 3F). In our experiment, resorption of tubers always occurred during plant senescence (i.e. when dry weights of the non-tuber fraction decreased). Due to the tuber inducing conditions and the high plant density of 350 plants $\mathrm{m}^{-2}$, the plants completed their growth cycle very rapidly. Larger decreases in tuber number (Figs. 2A and 2B), were associated with lower (more negative) GRs of the non-tuber fraction (Table 3).

\section{Tuber growth after a first non-destructive harvest}

In general, the number of tubers $\geqslant 0.3 \mathrm{~g}$ did not decrease during tuber resorption (Figs. 2C and 2D). Thus, it seems plausible that in our experiment an individual tuber weight of $0.3 \mathrm{~g}$ was large enough to become a competitive tuber. Only in strongly senescing, deteriorating plants, when even tuber GRs became negative (Table 3 ), a decrease in number of tubers $\geqslant 0.3 \mathrm{~g}$ was observed. However, no significant increase in number of tubers $\geqslant 0.3 \mathrm{~g}$ was observed either, later than 3 weeks after a non-destructive harvest (Figs. 2C and 2D). This shows that prolonging the growing period, and thus increasing the total amount of assimilates, was not effective in increasing the number of tubers $\geqslant 0.3 \mathrm{~g}$.

High numbers of tubers initiated, may increase the number of tubers that can grow 
to a size of $\geqslant 0.3 \mathrm{~g}$, provided tuber GRs are sufficiently high. Under field conditions, MacKerron et al. (1988) observed more uniform tuber sizes of tubers $>15 \mathrm{~mm}$ at higher tuber numbers. In our experiment, the timing of the first non-destructive harvest strongly affected the number of tubers initiated within 3 weeks after a first harvest in cv. Bintje (Fig. 2B), while tuber GRs were similar (Table 3). Higher numbers of tubers initiated indeed were associated with higher numbers of tubers $\geqslant 0.3 \mathrm{~g}, 3$ weeks after a non-destructive harvest. Thus, the timing of the first harvest also affected the number of tubers $\geqslant 0.3 \mathrm{~g}$ that was produced finally. Differences between cultivars were remarkable. In $\mathrm{cv}$. Ostara, less tubers were initiated after a first non-destructive harvest than in cv. Bintje (Fig. 2), while tuber GRs were similar (Table 3). Moreover, in cv. Ostara, a smaller proportion of the initiated tubers did grow to a size of $\geqslant 0.3 \mathrm{~g}$ within 3 weeks (Table 1), thus becoming unlikely to be resorbed.

Low tuber GRs during the 3 weeks interval after a non-destructive harvest, however, may reduce the proportion of the initiated tubers that can grow to a size of $0.3 \mathrm{~g}$ within 3 weeks under almost similar conditions: Lommen \& Struik (1992) showed that postponing a non-destructive harvest reduced tuber GRs more than tuber initiation. This was reflected in much lower numbers of tubers $\geqslant 0.3 \mathrm{~g}, 3$ weeks after a non-destructive harvest. In our experiment, however, averaged weights of all tubers were much higher than $0.3 \mathrm{~g}$ (Table 1). Thus, differences in initial weight and/or growth rates between individual tubers must have influenced the proportion of tubers that could grow to a size of $\geqslant 0.3 \mathrm{~g}$.

\section{Tuber initiation and resorption after a second non-destructive harvest}

Three weeks after a second non-destructive harvest, no initiation of new tubers was observed, except in cv. Ostara harvested non-destructively after 4 and 7 weeks (Fig. 3A). In general, tuber numbers remained constant or declined (Figs. 3A, 3B, 3E and 3F). There could be several possible explanations for the difference in response after a first and a second non-destructive harvest: (a) the number of possible tuber sites was limited, (b) the tubers that remained on the plant after a harvest because they had not reached the desired size became dominant before new tubers were initiated, (c) the newly initiated tubers were already resorbed before the plants were analyzed and (d) plants approached senescence and tuber initiation period had ended. The age of the plants itself (possibility d), most probably did not prevent initiation of tubers. Under similar conditions, Lommen \& Struik (1992) observed extensive initiation of tubers even when senescing plants were harvested non-destructively for the first time. The first three possible explanations, however, can not be ruled out.

The number of tuber sites is not accurately known, but might have been limiting. Many sites had already been occupied by removed tubers, and plants, including stolons, were seriously senescing at the time of the second harvest. The different response of cv. Ostara, harvested non-destructively after 4 and 7 weeks (treatment $4+7+10$ ), supports the view that the number of tuber sites may have limited tuber initiation. In this treatment, plants were less senescent than older plants and less tuber sites had been occupied thus far compared to cv. Bintje (Figs. 2A and 2B). On 
the other hand, formation of above-ground tubers is often observed when plants are induced to tuberize and tuber sites below ground are lacking, for instance after removing stolons plus tubers (Abdel-Waheb \& Miller, 1963; Paiva et al, 1983). In our experiment, above ground tubers were formed only incidentally and not significantly more after a second non-destructive harvest than without this non-destructive harvest (results not shown).

A second explanation is a rapid restoration of dominance by tubers remaining on the plant. More tubers remained on the plant after a second non-destructive harvest than after a first non-destructive harvest (Figs. 3A, 3B, 3E and 3F), and often more tubers remained on the plant than were likely to set and start bulking. Marschner et al. (1984) observed a restoration of normal tuber growth rates, 4 days after removal of all fast growing tubers, thus dominance in our experiment, could have been restored very rapidly. In favour of this second explanation is the different change in tuber number after the second harvest of plants harvested non-destructively after 4 plus 8 weeks (Figs. 3A and 3B) and after 5 plus 8 weeks (Figs. 3E and 3F). In the latter treatment, more tubers remained on the plant after the second harvest, resulting in a decrease in tuber number after the second harvest. In the first treatment less tubers remained on the plant and tuber numbers did not change.

Finally, already some resorption may have occurred within the 3 weeks after the second non-destructive harvest, because plants were seriously senescing after the second harvest. This view is supported by the fact that extending the growing period from 3 to 4 weeks after the second non-destructive harvest, tended to decrease the number of newly initiated tubers in cv. Ostara (Fig. 3A).

\section{Tuber growth after a second non-destructive harvest}

The number of tubers $\geqslant 0.3 \mathrm{~g}$ always increased after a second non-destructive harvest, regardless of how total tuber numbers changed (Figs. 3C, 3D, 3G and 3H), and their average weight in general was higher than $1 \mathrm{~g}$ (Table 5). The increase in number of tubers $\geqslant 0.3 \mathrm{~g}$ indicates that a second harvest stimulated the growth of tubers that would have been resorbed or had not reached the final phase in tuber formation without a second non-destructive harvest. Only around half of all tubers was $\geqslant 0.3 \mathrm{~g}$ (Table 5), but the average fresh weight of all tubers was higher than 0.3 g. Therefore, again, differences in initial weight or growth rates between individual tubers must have influenced the proportion of tubers growing to a size of $\geqslant 0.3 \mathrm{~g}$ after a second non-destructive harvest.

Fitting in the effect of a non-destructive harvest into the general concept of tuber formation

Based on papers by Struik et al. (1988) and Vreugdenhil \& Struik (1989), eight phases can be distinguished in the process of tuber formation: (1) stolon induction, (2) stolon initiation, (3) stolon growth, (4) cessation of stolon growth, (5) tuber induction, (6) tuber initiation, (7) tuber set and (8) tuber growth. Tuber resorption, however, can replace tuber set and tuber growth. Before the first non-destructive harvest, at least part of the tubers was already growing rather rapidly. Initiation of 
more tubers was limited, most probably by the lack of tuber sites that were not subjected to the dominance of the rapidly growing tubers. At a non-destructive harvest, the tubers that were most advanced in the process of tuber formation, were removed. Thereafter, many new tubers were initiated. Only a part of them was able to grow through all phases of tuber formation. Plants were already senescing by then and many tubers were resorbed if plants were left undisturbed after the first harvest. If, instead, plants were harvested non-destructively a second time, the tubers removed again included the dominant tubers that could prevent the initiation or growth of other tubers. After removal of these, tubers that would have been resorbed or had not reached the final phase in tuber formation yet, were able to develop further.

\section{Growth reductions after a non-destructive harvest}

The long-term (5-7 weeks) reduction in tuber and overall growth caused by a first non-destructive harvest, was most severe when older plants were harvested nondestructively (Table 4). This is in accordance with previous results (Lommen \& Struik, 1992) in which it was shown that 3 weeks after a non-destructive harvest, growth was reduced most in senescent plants. This was attributed to the senescent plants not being able to adapt after the non-destructive harvesting procedure, in which not only tubers were removed, but which also caused root damage.

Like the first non-destructive harvest, a second harvest again caused a severe reduction in overall and tuber GRs, compared to plants left undisturbed after a first non-destructive harvest (Table 6). This reduction in growth will have similar causes as the reduction observed in rather old plants after a first non-destructive harvest (Lommen \& Struik, 1992). If old plants ( 8 weeks) were harvested non-destructively a second time, however, even overall GRs were only slightly positive or negative. We surmise that in those cases most of the gain in tuber dry weight was caused by redistribution from the non-tuber plant fraction.

The reduction in tuber GRs after a second non-destructive harvest, compared to undisturbed growth after a first non-destructive harvest, implies that under circumstances where no significant gain in tuber numbers can be expected (Fig. $4 \mathrm{H}$ ), a second harvest will only reduce tuber yield.

\section{Practical implications}

For commercial production of high numbers of minitubers, all larger tubers from non-destructive and final harvests can be used. The procedure described in this paper, growing plants under tuber inducing conditions at a plant density of 350 plants $\mathrm{m}^{-2}$ and using two non-destructive harvests of tubers $\geqslant 0.3 \mathrm{~g}$ and a third and final harvest, proved to be a suitable method for producing high numbers of minitubers, both per $\mathrm{m}^{2}$ and per plantlet. The first non-destructive harvest stimulated the initiation of new tubers and the second non-destructive harvest in general stimulated the set and growth of tubers which otherwise would have remained small or would have been resorbed.

With a production scheme using intervals of 3 weeks between harvests, high numbers of tubers were obtained in both cultivars; the first harvest could be carried 
out around 4 weeks after transplanting (harvest scheme $4+7+10$ ). Using this method 1740 minitubers per $\mathrm{m}^{2}$ were produced in cv. Ostara, and 1946 in cv. Bintje in 10 weeks. These minitubers had average weights higher than $1 \mathrm{~g}$ (Tables 1 and 5). For some cultivars, however, a harvest scheme consisting of only 2 harvests may be used. In cv. Bintje, a second non-destructive harvest was less effective in increasing the combined number of minitubers; higher yields and tuber numbers could therefore be obtained in a production scheme with only 2 harvests (harvest scheme $5+11$ ). However, in this scheme the timing of the first harvest was very critical. The optimal moment could not be assessed on the basis of the plant habitus. Using a 3-harvests scheme would therefore be more safe. Optimizing the production technique for minitubers and establishing their storage behaviour and field performance, will be reported in forthcoming papers.

\section{Acknowledgements}

We thank Ms. E. van Heusden for her excellent assistance and S.B.S.A. (Slootdorp, Netherlands) for supplying the in vitro plantlets. Part of this research was financed by the Dutch Commodity Board for Potatoes.

\section{References}

Abdel-Wahab, A.E. \& J.C. Miller, 1963. Re-evaluation of some techniques and their effect on stimulating flowering in four Irish potato varieties in Louisiana. American Potato Journal 40: 53-57.

Cho, J.L. \& W.M. Iritani, 1983. Comparison of growth and yield parameters of Russet Burbank for a two-year period. American Potato Journal 60: 569-576.

Ewing, E.E. \& P.C. Struik, 1992. Tuber Formation in Potato: Induction, Initiation and Growth. Horticultural Reviews 14: 89-198.

Krug, H. \& W. Wiese, 1972. Einfluss der Bodenfeuchte auf Entwicklung und Wachstum der Kartoffelpflanze (Solanum tuberosum L.). Potato Research 15: 354-364.

Lommen, W.J.M. \& P.C. Struik, 1992. Influence of a single non-destructive harvest on potato plantlets grown for minituber production. Netherlands Journal of Agricultural Science 40: 21-41.

MacKerron, D.K.L., B. Marshall \& R.A. Jefferies, 1988. The distribution of tuber sizes in droughted and irrigated crops of potato. II. Relation between size and weight of tubers and the variability of tuber-size distributions. Potato Research 31: 279-288.

Marschner, H., B. Sattelmacher \& F. Bangerth, 1984. Growth rate of potato tubers and endogenous contents of indolylacetic acid and abscisic acid. Physiologia Plantarum 60: 16-20.

Murashige, T. \& F. Skoog, 1962. A revised medium for rapid growth and bio assays with tobacco tissue cultures. Physiologia Plantarum 15: 473-497.

Nösberger, J. \& E.C. Humphries, 1965. The influence of removing tubers on dry-matter production and net assimilation rate of potato plants. Annals of Botany 29:579-588.

Oparka, K.J., 1987. Influence of selective stolon removal and partial stolon excision on yield and tuber size distribution in field-grown potato cv. Record. Potato Research 30: 477-483.

Paiva, E., R.M. Lister \& W.D. Park, 1983. Induction and accumulation of major tuber proteins of potato in stems and petioles. Plant Physiology 71: 161-168.

Struik, P.C., E. van Heusden \& K. Burger-Meyer, 1988. Effects of short periods of long days on the development, yield and size distribution of potato tubers. Netherlands Journal of Agricultural Science 36: 11-22.

Vreugdenhil, D. \& P.C. Struik, 1989. An integrated view of the hormonal regulation of tuber formation in potato (Solanum tuberosum). Physiologia Plantarum 75: 525-531. 